\title{
JOURNAL.RU
}

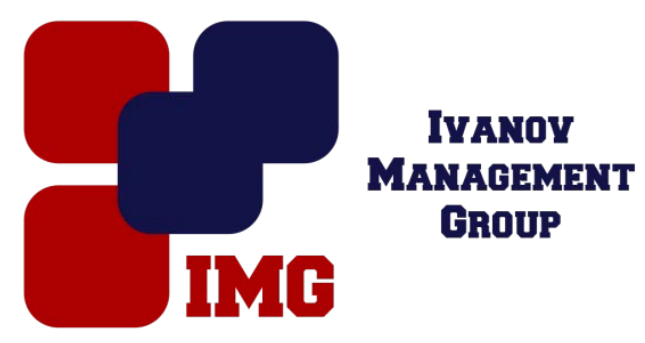

Перькова М. В., Найденова И.В. Белгородский государственный технологический университет им. В. Г. Шухова Белгород, Россия

doi: 10.18411/lj-31-01-2017-4-13

idsp 000001:lj-31-01-2017-4-13

\section{Особенности планировочной структуры и перспективы развития городов с преобладанием горнодобывающей промышленности}

\section{Аннотация}

В статье рассматриваются особенности градостроительного развития муниципальных единиц, образовавшихся под воздействием схожих природных и исторических факторов, на примере двух городов Белгородской области Губкина и Строителя.

Ключевые слова: горнодобывающая промышленность, промышленные моногорода, планировочная структура города,

Белгородскую область можно отнести к числу наиболее активно развивающихся регионов России. Здесь сложился аграрно-индустриальный тип экономики, прочную базу которого обеспечивает сочетание благоприятных климатических условий и плодородных почв с участками залегания полезных ископаемых. На территории области еще в 50-е гг. XX в. началась разработка железистых кварцитов, и в настоящий момент здесь имеются перспективные месторождения, что создает условия для дальнейшего развития горнодобывающей отрасли в регионе.

Для того, чтобы проследить динамику изменения показателей распределения объемов промышленного производства в разрезе муниципальных образований региона за прошедшие 13 лет, была составлена диаграмма на основе статистических данных (в млрд. рублей), приведенных в отчете о результатах деятельности правительства Белгородской области в 2015 г. (рис. 1б).

1a)

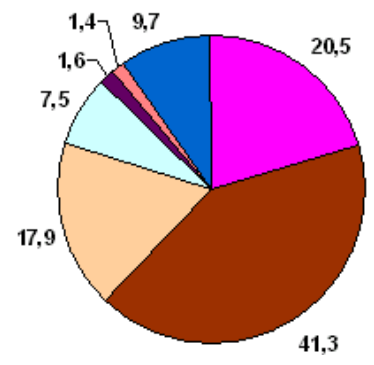

口Белгород

- Старый Оскол

口Губкин

口Алексеевка

- Шебекино

口Вапуйки

口Все районы обпасти (21)
16)

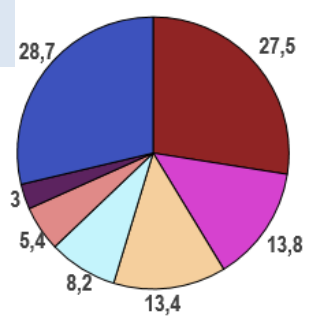

口 Старооскольский г.о.

г. Белгород

口Губкинский г.о

口Алексеевский р-н и г.Алексеевка

口г. Валуйки и Валуйский р-н

- Шебекинский р-н и г.Шебекино

- Все районы области (16)

Рис. 1. Вклад отдельных городов и районов в объем промылиленного производства области, \%: 1a) даннье за 2002 г. [2]; 16) данные за 2015 2. 
На основе данных (рис. 1) можно сделать вывод, что за последние 13 лет вклад Старооскольско-Губкинской агломерации в общий объем промышленного производства области сократился на $17,1 \%$; с 59,2\% до 42,1\%. Эту тенденцию можно во многом объяснить активным развитием сельского хозяйства и увеличением доли обслуживающих его отраслей промышленности в объеме валового регионального продукта (30\% в настоящий момент, в то время как 10 лет назад она составляла $18 \%$ ). Однако значимость горнодобывающей отрасли для экономической стабильности региона остается, по-прежнему, крайне высокой.

Относительно предприятий добывающей отрасли можно сказать, что они, зачастую, являются важнейшим условием функционирования и развития экономической и пространственной структуры городов. Это в большей степени касается городов с численностью населения до 100 тысяч (так называемых «малых» и «средних»). К категории таких городов, основу экономического благополучия которых составляет горнорудная промышленность, в Белгородской области относятся Губкин и Строитель.

Единственный моногород в составе Белгородской области - г. Губкин, относящийся к числу средних городов, - является классическим примером промышленного города-спутника со стабильной экономической ситуацией. Населенный пункт, возникший в качестве рабочего поселка в 1939 г. на месте обнаружения богатых железных руд вблизи сёл Коробково и Салтыково [3], получил статус города в 1955, разработка руд Лебединского месторождения ведется с 1959 г.

Строитель является самым «молодым» среди других городов Белгородской области. Город образован в 1958 г. как рабочий поселок в связи с освоением перспективного Яковлевского месторождения богатых железных руд.

Сходство природных факторов образования населенных пунктов могло послужить причиной схожего однонаправленного развития Губкина и Строителя. Однако, существующие гидрогеолгические условия местности не позволили вести разработку Яковлевского месторождения вплоть до 1997 г., когда была добыта первая тонна богатой железной руды. В настоящее время г. Строитель, который тяготеет к типу моногорода [4], называют третьей железнорудной «столицей» области.

Расположение месторождений полезных ископаемых в городской сети и непосредственно способ добычи руды оказывают существенное влияние на развитие планировочной структуры городов. Строитель характеризуется свободной структурой, структура Губкина тяготеет к рассредоточенному типу, что свойственно городам с преобладанием добывающей отрасли промышленности.

Территория ОАО «Лебединский ГОК» частично расположена вдоль восточной границы г. Губкина ниже р. Осколец и простирается в южном направлении. Лебединский ГОК относится к предприятиям II класса вредности, что предполагает зашитную зону шириной 500 м. Функциональная структура Губкина четко выражена: селитебная зона главным образом сконцентрирована выше магистрльной железной дороги вдали от промзоны.

Яковлевский рудник расположен в пгт Яковлево Яковлевского района севернее районного центра - г. Строитель. Разработка месторождения закрытым способом ведется с 2006 г. Такой способ добычи является дорогостоящим, но в то 
же время наносит, в сравнении с открытым, меньший вред окружающей среде и относится к III классу опасности.

Важным показателем градостроительного развития территорий является показатель ввода жилья на душу населения, здесь Яковлевский район в 2015 г. занял второе место среди муниципальных образований Белгородской области, Губкинский городской округ стал четвертым $(0,9$ и 0,75 кв. м. на душу населения соответственно).

На рис. 2 размещены зоны проектируемой жилой застройки. Строитель является одной из активно развивающихся территориальных единиц Белгородской области. В рамках существующих прогнозов развития, новая застройка существенно расширит границы городского поселения «Город Строитель» в северном и северо-восточном направлениях вдоль существующих автомобильных дорог. Яковлевский рудник, представляющий собой одно из главных градообразующих предприятий, своим расположением не влияет на развитие планировочной модели.

С другой стороны, проектируемая жилая застройка в границах г. Губкин вписывается в градостроительную модель, характерную для промышленных моногородов. В связи с ухудшением состояния природной среды в районе Губкинско-Старооскольского района КМА под действием техногенной нагрузки, требуется комплексный подход к восстановлению и рекультивации нарушенных земель.

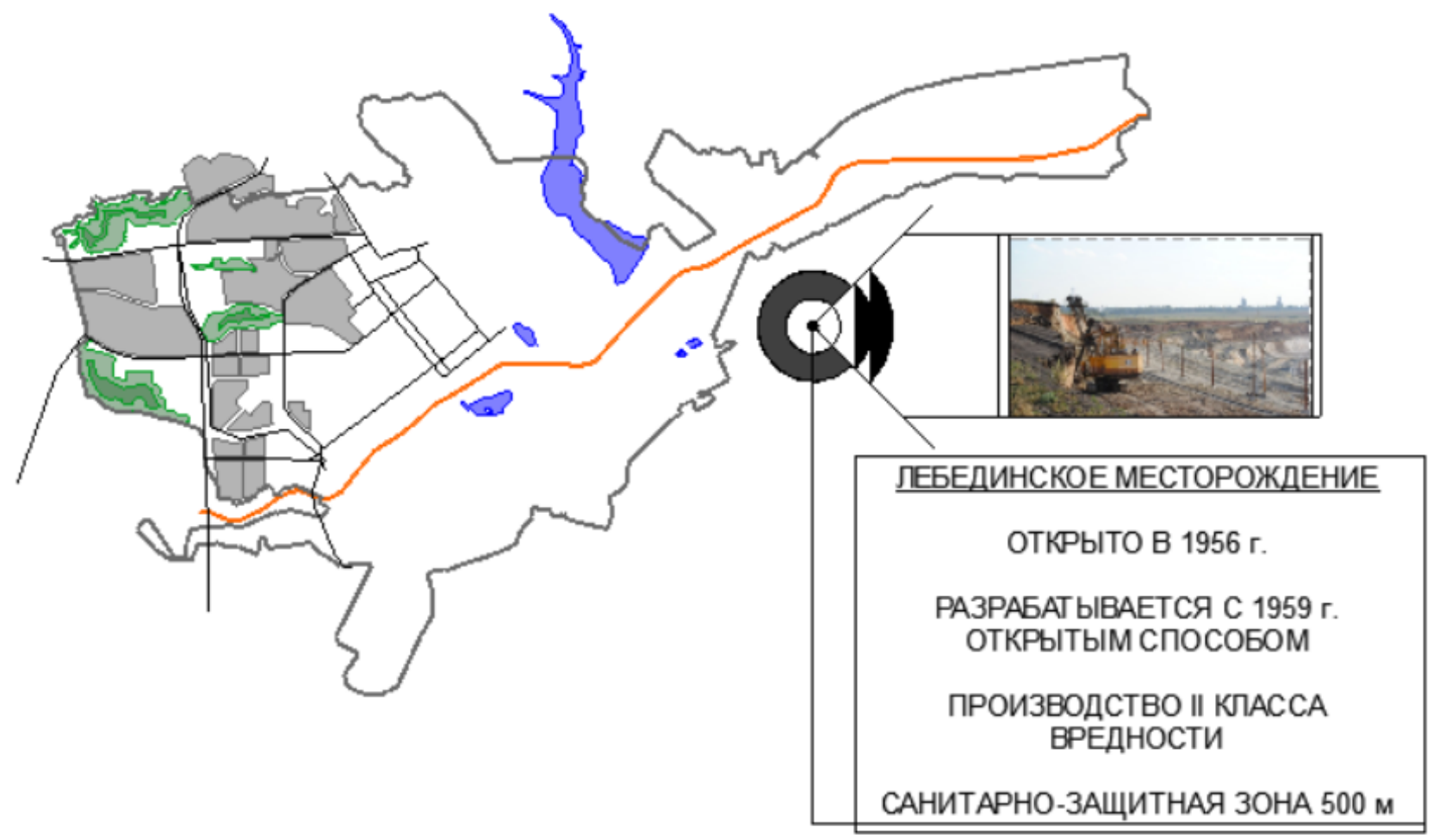




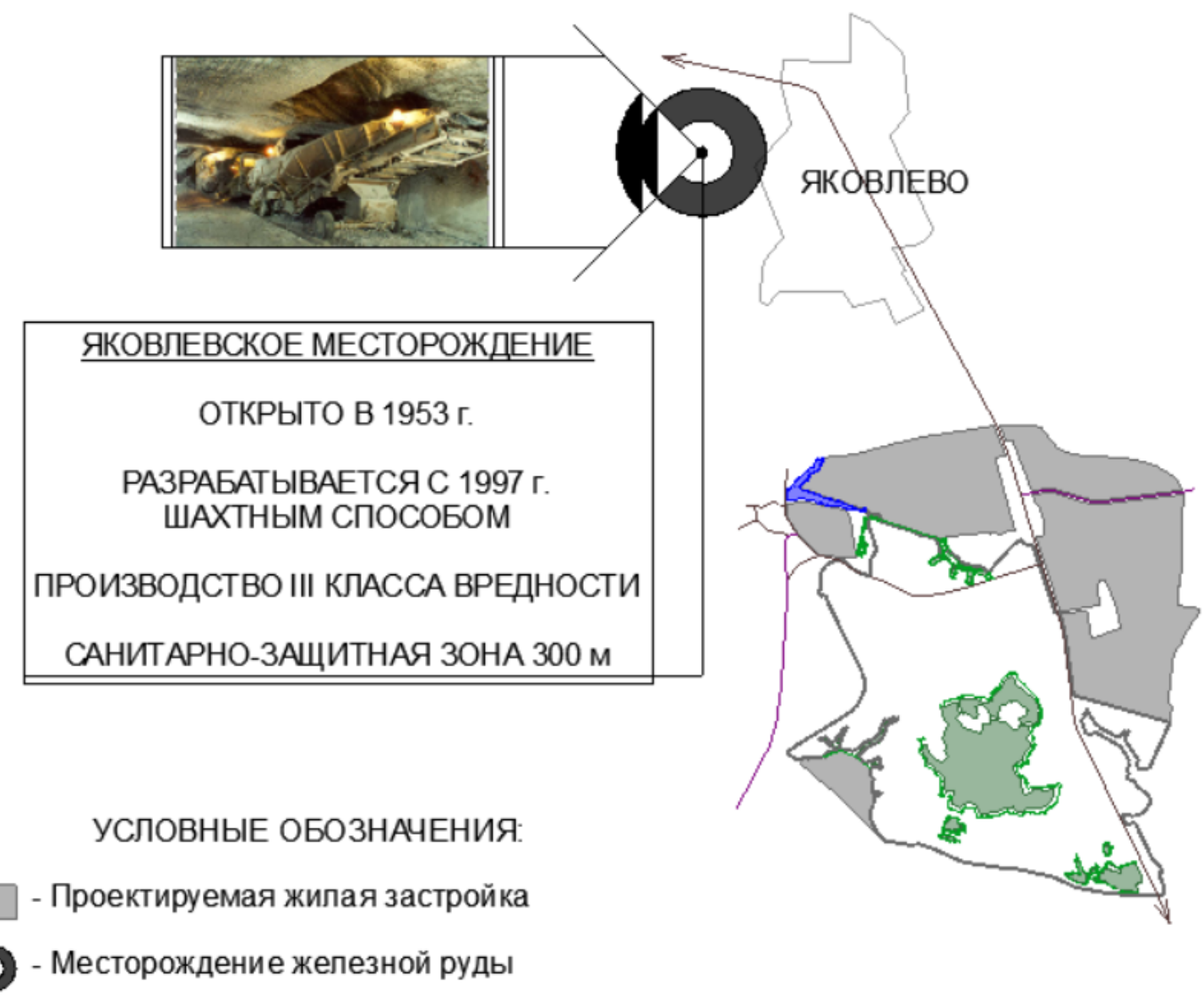

26

Рис. 2. Схема планируемого развития жилой застройки: 2а) г. Губкин; 2б) городское поселение «Город Строитель»

В условиях переходной экономики моногорода и города с преобладанием добывающей промышленности являются наиболее уязвимыми. Однополярный подход к развитию территории может иметь крайне негативные последствия, что можно наблюдать во многих малых городах России.

В структуре экономического развития единственного моногорода Губкина постепенно происходит смещение вектора в сторону укрепления агропромышленного сектора экономики, в настоящее время на территории Губкинского г. о. активно развивается сельское хозяйство, мясо-молочное производство, что позволит наилучшим образом реализовать природно-ресурсный потенциал территорий. Несмотря на то, что перспективы дальнейшего развития г. Строитель во многом связывают с разработкой Яковлевского месторождения, его экономическую структуру нельзя назвать монопрофильной. При дальнейшем грамотном подходе, это позволяет строить благоприятные прогнозы развития городов Губкина и Строителя. 


\section{Литература}

1. Отчёт Губернатора области Евгения Савченко о результатах деятельности Правительства Белгородской области в 2015 году [Электронный ресурс] // Губернатор и Правительство Белгородской области. - Белгород, 2006-2017. Режим доступа: http://www.belregion.ru/press/important.php?ID=14748. 3.10.2016.

2. Белгородская область [Электронный ресурс] // Социальный атлас российских регионов. - 2002-2017. - Режим доступа: http://atlas.socpol.ru/portraits/bel.shtml. 3.10.2016.

3. Горная энциклопедия [Электронный ресурс]. В 5 т.; гл. ред. Е. А. Козловский. Том 3. Кенган - Орт. - Москва : Советская энциклопедия, 1987. - 592 с. - Мир энциклопедий. - $1997-2017 . \quad$ http://dic.academic.ru/dic.nsf/enc_geolog/2676/Курская. - 3.10.2016.

4. Перькова М.В., Борзых Е.В. Оценка взаимосвязи социальных и пространственных факторов в планировке г. Строитель: сб. науч. тр. / Вестник БГТУ им. В.Г. Шухова, 2015. Вып. 6. С. 134-138.

5. Перькова М.В. Особенности градостроительного развития элементов и сети малых городов Белгородской области: сб. науч. тр./ Белгор. гос. технол. ун-т. Белгород: Изд-во БГТУ, 2014. Вып. 6. 